\title{
Textile Palm Fibers from Amazon Biome
}

\author{
Lais Gonçalvez Andrade Pennas ${ }^{1, a}$, Ivete Maria Cattani ${ }^{1, b}$, Barbara Leonardi ${ }^{1, c}$, \\ Abdel-Fattah M. Seyam ${ }^{2, d}$, Mohamad Midani ${ }^{2,3, e}$, Amanda Sousa Monteiro, ${ }^{1, f}$, Julia \\ Baruque-Ramos ${ }^{1, g^{*}}$ \\ ${ }^{1}$ University of Sao Paulo, School of Arts, Sciences and Humanities, Av. Arlindo Bettio, 1000; \\ 03828000, Sao Paulo, SP, Brazil \\ ${ }^{2}$ North Carolina State University, College of Textiles, 1020 Main Campus Drive, Raleigh, NC \\ 27606, USA \\ ${ }^{3}$ German University in Cairo, College of Engineering and Materials Science, Al Tagamoa Al \\ Khames, Cairo, Egypt \\ a laiis_s@hotmail.com, b ivetecattani@me.com, ${ }^{\mathrm{c}}$ leonardi.ba@gmail.com, ${ }^{\mathrm{d}}$ aseyam@ncsu.edu, \\ emsmidani@ncsu.edu, ${ }^{\mathrm{e}}$ amandasousamont@gmail.com, ${ }^{9}$ jbaruque@usp.br
}

Keywords: textile; palm fibers; Amazonia; Brazil; tucum; buriti; tururi; composite

\begin{abstract}
There are several species of Amazon palm trees from which can be obtained: food and oils (fruits and seeds), medicinal products, construction material (logs and leaves), handicraft, textiles, etc. Taking in account textile fibers, three palm origins stand out: tucum (Astrocaryum chambira Burret), buriti (Mauritia flexuosa Mart.) and tururi (Manicaria saccifera Gaertn.). Tucum fibers, obtained from grown leaves, are used in the manufacture of fabrics, handicrafts, nets, yarns and fishing nets. Buriti presents multiple uses, especially for handicraft products. A soft fiber ("linen") and another harder and rougher ("draff") are removed from the young leaves of the buriti palm, both being used. Tururi is the sac that wraps the fruits of the Ubuçu palm tree. The material is constantly used by the Amazonian riverside population and by artisans for handicrafts, fashion items and other products for tourism. In a joint project of the North Carolina State University (USA) and University of São Paulo (Brazil), multilayer composite materials were developed and characterized in 3D structure with quite promising results in terms of resistance and aesthetic finish similar to wood. Thus, the traditional and innovative uses of native vegetable fibers are ways of valuing the regional product and preserving their respective ecosystems.
\end{abstract}

\section{Introduction}

The Amazon biome comprises an area of 410 million hectares and is formed by three types of forests: dry land, wet land and flooded area. It encompasses extensive areas of "cerrados" (kind of savannas) and meadows. The Amazon biome develops around the Amazon basin and is present in eight countries of South America [1]. There are several species of palm trees from the Amazon biome, from which can be obtained: food or oils (fruits and seeds), biodiesel, medicinal and cosmetic uses, construction material (logs and leaves), handicraft material, including fibers for textile purposes, etc. Some examples are [2]: Açai (Euterpe precatoria); Cocao (Attalea tessmanii); Inaja (Attalea maripa); Jaci (Attalea butyraceae); Jarina (Phytelephas macrocarpa); Murmuru (Astrocaryum murumuru); Paxiubao (Iriartea deltoidea); Paxiubinha (Socratea exorrhiza); and Pataua (Oenocarpus bataua). The incentive for the employment of native vegetable fibers as an alternative textile material can increase local productivity and improving the income of the populations. Another point is that there is enormous creative potential. Aiming 
at technology, there is growing international interest in the use of these vegetable fibers, especially as non-conventional materials for the manufacture of composites instead of those made with wood or synthetic materials [3]. Taking in account the obtainment of textile fibers, three palm origins stand out: tucum buriti and tururi. A briefing enrolling the obtention of fibers, processing and manufacture of final products in shown in Figure 1.

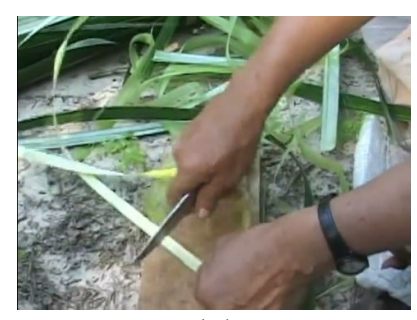

(a)

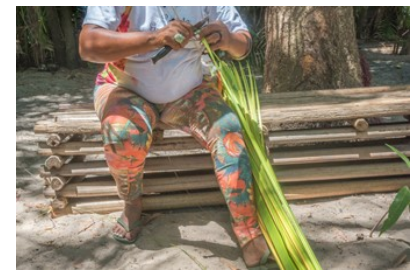

(d)

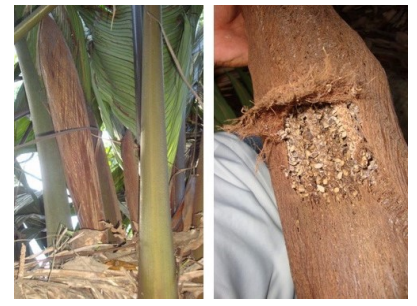

(g)

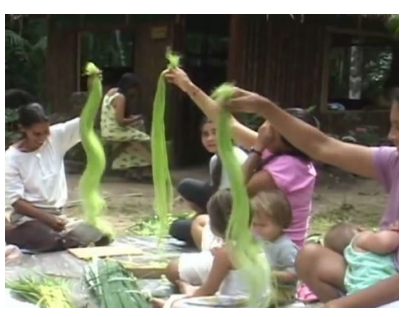

(b)

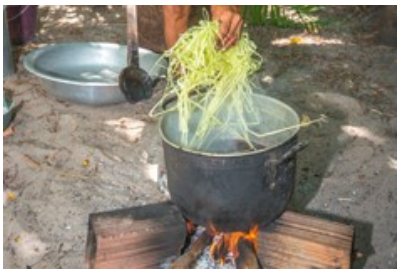

(e)

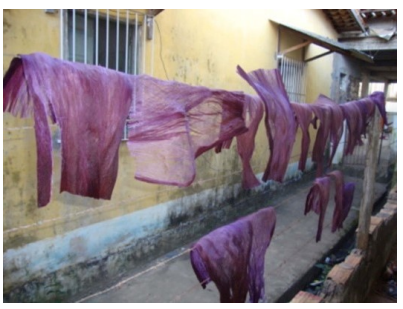

(h)

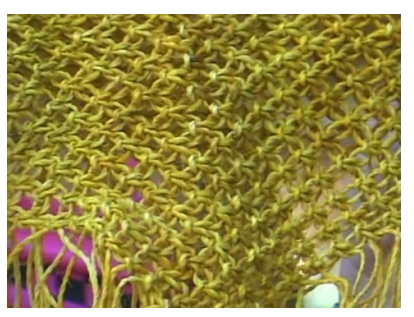

(c)

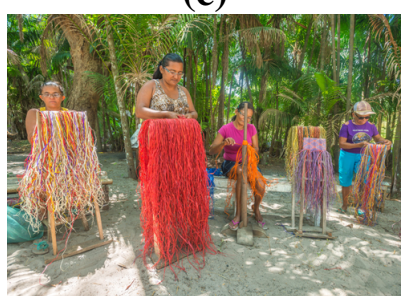

(f)

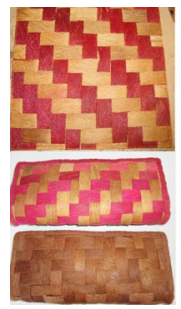

(i)

Figure 1. Tucum: (a) Obtention from grown palm leaves [4]; (b) Processing of obtained fibers [4]; (c) Macrame fabric [4] [5]. Buriti: (d) Obtention of "linen" and "draff" fibers from the young leaves [1] [6] [7] [8]; (e) Dyeing of fibers [1] [6] [7] [8]; ( $f$ ) Working in manual looms [1] [6] [7] [8]. Tururi: (g) Sac covering the fruits in the palm and after collection [9] [10]; (h) Drying of tururi mats after dyeing [9] [10]; $(\mathrm{g})$ Mat, bags and composite made from tururi [9] [10] [11].

In the present study the main physical-chemical characteristics of these palm fibrous material were compared and for tururi also the characteristics of composite structures were presented.

\section{Material and methods}

The fibers were taken respectively from: (i) Grown leaves of tucum palm trees (Astrocaryum chambira Burret), in the Community Ecological Village of Jurua, municipality of Ipixuna,

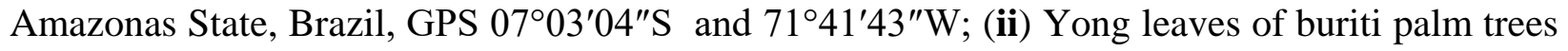
(Mauritia flexuosa Mart.), located in Marcelino Village, situated on the bank of "Preguiça” river, Barreirinhas city, Maranhao State, Brazil, GPS 0245'18,8101"S and 4249'04,2782"W; (iii) Sacs of tururi (Manicaria saccifera Gaertn), in the cities of Sao Sebastiao da Boa Vista and Muana, Para State, Brazil, central GPS positions respectively S - ${ }^{\circ} 23$ '53.4156"W 49³8'14.9928" and S-1²0'40.3506 "W-49¹7'45.3948". All locations are in comprised in Brazilian Amazon Forest biome and in all cases, the prospection radius was 5,000 m. It should 
be noted that obtaining these specimens does not require authorization from IBAMA (Brazilian Institute of Environment) or any other federal or state environmental agency, since the material is usually collected and marketed and its purchase and possession has no legal restriction in any of the Brazilian states. Other fibers employed in the present study, originated from the leaf of following plants, are: i) curaua (Ananas erectifolius) provided by the Federal University of Amazonas, produced in that Brazilian state; and ii) sisal (Agave sisalana) purchased in Sao Paulo city, while originating from Bahia state (both Brazilian regions).

The assays were performed at $20^{\circ} \mathrm{C}$ and $65 \%$ relative humidity (ABNT NBR ISO 139:2005) [12]. Cross microscopy structures were determined according to ABNT NBR 13538-1995 [13]. They were carried out on cross-sections of resin encapsulated fibers cut in rotational semiautomated microtome (Leica, RM 2245 model, Germany). The materials were analyzed in biological microscope (Leica, BME model, Germany) coupled to camera video digital imaging (Sony Color VideoCamera ESWAVEHAD, 55C-DC93-P model, China). All the obtained images were captured and processed by Video Analyzer 2000 system (Mesdan, Italy).

Tensile properties of the fibers (rupture load, elongation, tenacity and Young's modulus), from buriti and tucum fibers samples (obtained respectively from young and grown leaves) and fibers withdrawn from tururi sacs, were determined according to ASTM D 3 822-2001 [16] employing tester machine Instron (model 5569, Norwood, USA). Formerly, in order to determine tenacity (strength value shared by count number) fiber fineness (linear density or count number) was calculated in terms of TEX, defined as the weight in grams per $1,000 \mathrm{~m}$ of the fiber, by weighing a known length of the fiber. A gauge length of $25 \mathrm{~mm}$, automatic pre-tension and crosshead speed of $50 \mathrm{~mm} / \mathrm{min}$ and a cell of $1000 \mathrm{~N}$ were employed. The results are an average from at least twenty samples. The total length of the sample was approximately $100 \mathrm{~mm}$, sufficient to allow the distance between the jaws of $25 \mathrm{~mm}$.

The tenacity for fibers was determined by the presented in Equation 1 [14] [15]:

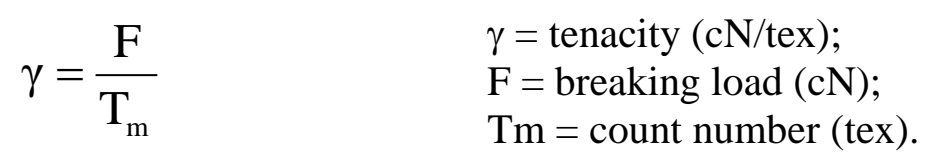

The Young's modulus (or textile initial modulus or module) of a fiber is determined by the slope of the tenacity-elongation curve in its initial linear part as presented in Equation 2 [15]:

$$
\text { Young's modulus }=\frac{\gamma_{1}}{\varepsilon_{1}} \quad \begin{aligned}
& \gamma_{1}=\text { Tenacity in the initial part of the tenacity- } \\
& \text { elongation curve (cN/tex) } \\
& \begin{array}{l}
\varepsilon_{1}=\text { elongation in the initial part of the } \\
\text { tenacity-elongation curve (\%) }
\end{array}
\end{aligned}
$$

In addition, tururi fibrous material from sacs was tested in order to determine the values of tensile strength (testing the fibers withdrawn from these sacs and testing strips from the sacs that forms this material - in natura and after discoloration) and weight. Tensile properties of the surface fibrous material (rupture load, elongation, strength and Young's modulus), from samples obtained from cut strips of the fibrous material from the sacs, were determined according to ABNT NBR 13041:1993 [17] employing tester machine Instron (model 5569, Norwood, USA), employing using a crosshead speed of $100 \mathrm{~mm} / \mathrm{min}$ and a cell of $1000 \mathrm{~N}$. The results are an average from at least twenty samples. The samples were $20 \mathrm{~mm}$ wide and $300 \mathrm{~mm}$ length. Jaws 
of rubberized grips with dimensions of $3.8 \times 5 \mathrm{~cm}$ were employed. The distance between the grips was $200 \mathrm{~mm}$. The thickness of the samples was previously determined employing portable analogical thickness gauge (model 188F, Mesdan, Italy).

In order to define the weight of the surface of fibrous material, ABNT NBR 12984:2000 [18] standard was employed. A total of 20 samples of size 5.0 × $5.0 \mathrm{~cm}$ were tested. The samples were weighed on analytical balance (Sartorius, ED124S model, Germany). The weight calculation was calculated as $\mathrm{g} / \mathrm{m}^{2}$.

Regain determinations were performed according the method adapted from ISO/TR 6741-4: 1987 [19]. Percent Moisture Regain (or "Regain") is defined as the weight of water calculated as a percentage of dry weight. After acclimatization at $20^{\circ} \mathrm{C}$ and $65 \%$ relative humidity [13] [14] [15] the samples were weighed on analytical balance (Sartorius, ED124S model, Germany). The drying was performed in an oven with forced air circulation (Binder FD Model 115, Germany) at $70^{\circ} \mathrm{C}$ for $24 \mathrm{~h}$ or more until constant weight and the sample was again weighed. Twenty repetitions of each group were analyzed.

For tucum fiber, DSC, TGA and XRD tests were performed. DSC (Digital Scanning Calorimetry) and TGA (Thermogravimetry Analysis) tests were carried out in Thermogravimetric Analyzer Mettler Toledo (model TGA/DSC 2, Netherlands), temperature from 30 to $1000^{\circ} \mathrm{C}, 10^{\circ} \mathrm{C} / \mathrm{min}, 50 \mathrm{~mL} / \mathrm{min}$ nitrogen atmosphere and $70 \mu \mathrm{L}$ alumina crucible. For lignocellulosic materials, the events (peaks characterized by inflection points) in the DTG (Derivative Thermogravimetry) curves can be associated to processes that occur to the different constituents of the analyzed material. Thus, in many cases, the approximate composition of the analyzed lignocellulosic material can be estimated by comparing the DTG and TGA curves and compare those results with those obtained through chemical determination [20].

In addition, the XRD spectra were obtained at room temperature $\left(25^{\circ} \mathrm{C}\right)$ with a diffractometer Rigaku Miniflex 300 (Japan), Cu X-Ray tube, $\mathrm{K} \beta$ filter, $30 \mathrm{kV}$ and $15 \mathrm{~mA}$. Dispersion ranged from $4^{\circ}$ to $80^{\circ}, 2^{\circ} / \mathrm{min}$ continuous scan, $0.020^{\circ}$ sampling width and $2 \theta / \theta$ scan axis.

The tucum, buriti, tururi, sisal and curauá fibrous materials were analyzed by FTIR in equipment Thermo (model Avatar 370 FT-IR) employing cell of ATR / Germanium (Ge) (Nicolet, USA). The interval was from 4,000 to $700 \mathrm{~cm}^{-1}$, performing 32 scans with $2 \mathrm{~cm}^{-1}$ resolution. The data acquisition was performed by OMNIC software, version 4.1, 2011[21].

\section{Results and discussion}

Cross-sectional microscopies

The cross-sectional microscopies of fibers are presented in Figure 2. They match with other ones of recognized textile employability.

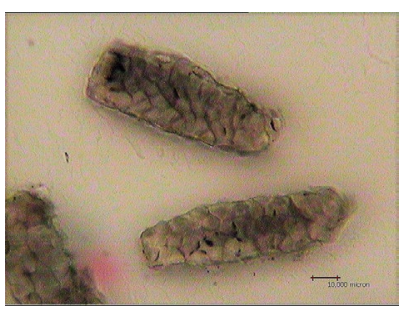

(a)

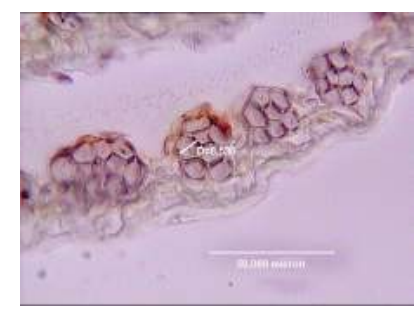

(b)

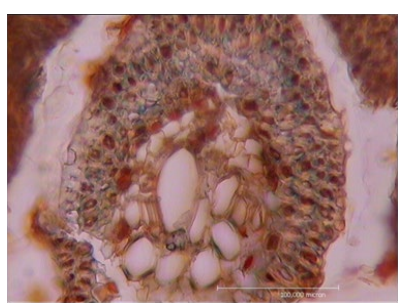

(c)

Figure 2. Cross microscopies: (a) Tucum: 1.280X magnification and $10 \mu \mathrm{m}$ scale [original data]; (b) Buriti “linen": 1.280X magnification and $50 \mu \mathrm{m}$ scale [1] [7] [22]; (c) Tururi: 640X magnification and $100 \mu \mathrm{m}$ scale [3] [9]. 
Despite of the similarities in the cross sections of studied species here and that ones from fibers of recognized textile employability, it cannot conclude, only through microscopic examination of their cross sections, the possible type of application for certain fiber. For this purpose, there is the necessity of a combined analysis of results from other physical and chemical tests. However, examination of cross sections by optical microscopy also is useful to evaluate the integrity of fiber cellular structure and the adequacy of procedures for processing of the fibers. The damage to cellular structures is visible such as deformation of cell shape [23]. The tucum cell diameter average value (from 10 determinations) is $5.5 \pm 1.5 \mu \mathrm{m}(\mathrm{CV}=27 \%$ ). For buriti "linen" is $8.5 \mu \mathrm{m}$ and for buriti "draff”, $7.2 \mu \mathrm{m}$. The tururi cell diameter average value (from 10 determinations) is $8.7 \pm 5.1 \mu \mathrm{m}(\mathrm{CV}=58.6 \%)$. This value is compatible with the values of species of recognized textile employability. According to Reddy and Yang ${ }^{25}$, the unit cell size ranges from 12.0 to $25.0 \mu \mathrm{m}$ for cotton, 5.0 to $76.0 \mu \mathrm{m}$ for flax and from 15.0 to $25.0 \mu \mathrm{m}$ for jute.

\section{Tensile and regain results}

The values for tensile and regain results on fibers of buriti, tucum and withdrawn from tururi sacs are presented in Table 1.

Table 1 - Tensile and regain results on fibers of buriti, tucum and withdrawn from tururi sacs. Values expressed by average, standard coefficient and variation coefficient.

\begin{tabular}{|c|c|c|c|c|c|c|c|c|}
\hline Fiber & & $\begin{array}{c}\text { Count } \\
\text { Number* } \\
\text { (tex) }\end{array}$ & $\begin{array}{c}\text { Rupture } \\
\text { Load } \\
\text { (N) }\end{array}$ & $\begin{array}{c}\text { Elongation } \\
(\%)\end{array}$ & $\begin{array}{l}\text { Tenacity } \\
\text { (cN/tex) }\end{array}$ & $\begin{array}{l}\text { Young's } \\
\text { Modulus } \\
\text { (N/tex) }\end{array}$ & $\begin{array}{c}\text { Regain } \\
(\%)\end{array}$ & References \\
\hline Tucum & & $\begin{array}{l}320 \pm 127 \\
(39.5 \%)\end{array}$ & $\begin{array}{l}119 \pm 49 \\
(41.0 \%)\end{array}$ & $\begin{array}{l}\mathbf{6 . 6} \pm 0.4 \\
(5.8 \%)\end{array}$ & $\begin{array}{c}\mathbf{3 7 . 4} \pm 5.6 \\
(14.9 \%)\end{array}$ & $\begin{array}{l}\mathbf{8 . 3} \pm 1.0 \\
(12.5 \%)\end{array}$ & $\begin{array}{c}\mathbf{1 0 . 0} \pm 0.3 \\
(3.4 \%)\end{array}$ & $\begin{array}{c}\text { [original } \\
\text { data] }\end{array}$ \\
\hline \multirow{2}{*}{ Buriti $^{* *}$} & linen & $\begin{array}{c}223 \pm 77.7 \\
(34.8 \%)\end{array}$ & $\begin{array}{c}64.1 \pm 27.4 \\
(43.6 \%)\end{array}$ & $\begin{array}{c}\mathbf{8 . 3} \pm 0.5 \\
(6.8 \%)\end{array}$ & $\begin{array}{c}28.4 \pm 5.5 \\
(19.6 \%)\end{array}$ & $\begin{array}{l}\mathbf{6 . 1} \pm 0.8 \\
(13.1 \%)\end{array}$ & $\begin{array}{c}\mathbf{8 . 5} \pm 0.3 \\
(2.6 \%)\end{array}$ & \multirow{2}{*}{ [1] [22] } \\
\hline & draff & $\begin{array}{c}228 \pm 134 \\
(47.7 \%)\end{array}$ & $\begin{array}{c}52.2 \pm 35.1 \\
(67.2 \%)\end{array}$ & $\begin{array}{l}\mathbf{5 . 0} \pm 0.8 \\
(15.5 \%)\end{array}$ & $\begin{array}{l}\mathbf{1 8 . 0} \pm 6.3 \\
(34.9 \%)\end{array}$ & $\begin{array}{l}\mathbf{6 . 0} \pm 1.6 \\
(25.9 \%)\end{array}$ & $\begin{array}{c}9.0 \pm 0.8 \\
(8.4 \%) \\
\end{array}$ & \\
\hline Tururi & & $\begin{array}{c}\mathbf{9 8 . 4} \pm 15.2 \\
(15.5 \%)\end{array}$ & $\begin{array}{l}17.7 \pm 4.2 \\
(23.5 \%)\end{array}$ & $\begin{array}{l}10.5 \pm 2 \\
(20 \%)\end{array}$ & $\begin{array}{c}18.0 \pm 3.2 \\
(18 \%)\end{array}$ & $\begin{array}{l}3.4 \pm 0.5 \\
(14.4 \%)\end{array}$ & $\begin{array}{c}12.0 \pm 0.5 \\
(4.3 \%)\end{array}$ & [3] [9] \\
\hline
\end{tabular}

*For buriti and tururi the expressed values represent the count number of single fibers. For tucum the expressed value represents the count number of fiber bundles employed in tests, since the single fibers are very thin (near 2.4 tex and $90 \pm 12 \mathrm{~cm}$ natural fiber length). ${ }^{* *}$ From buriti young leave two different fibers are obtained: one more flexible (popularly called "buriti linen”) employed in woven or knitted fabrics for fine handcrafts, and another one more rustic ("buriti draff”) employed for confection of basketry, sets of placemats, etc. 
Table 2 - Tenacity, elongation and Young's modulus values for species of recognized textile employability. Values adapted from the indicated references.

\begin{tabular}{cccccc}
\hline Fiber & $\begin{array}{c}\text { Elongation } \\
(\%)\end{array}$ & $\begin{array}{c}\text { Tenacity } \\
(\mathbf{c N} / \text { tex) }\end{array}$ & $\begin{array}{c}\text { Young's } \\
\text { modulus } \\
(\mathbf{N} / \mathbf{t e x})\end{array}$ & $\begin{array}{c}\text { Regain } \\
(\mathbf{\% )}\end{array}$ & References \\
\hline Sisal & $2-3$ & $35.3-44.1$ & 12.4 & 11 & {$[15][24][26][28]$} \\
Curaua & $4.5-6$ & $135-326$ & $30-80$ & 9 & {$[24][26][27]$} \\
\hline Cotton & $3-7$ & $26.5-43.3$ & $5.3-6.2$ & 8.5 & {$[15][24][25]$} \\
Hemp & 1.8 & $51.2-60.0$ & 19.4 & $8-12$ & {$[15][24]$} \\
Jute & $1.7-2.0$ & $26.5-51.2$ & 17.9 & 13.8 & {$[15][24][25][26]$} \\
\hline
\end{tabular}

A comparison between the determined values (Table 1) and the properties of other vegetal fibers (Table 2) was performed. The tenacity of tururi fiber is lower in relation to other analyzed fibers. It is comparable to the lower limit of this parameter for cotton and jute. The tenacity values for the other analyzed fibers are comparable to sisal (leaf fiber), cotton (seed fiber) and hemp and jute (stem fibers). All the values are inferior to the curauá (leaf fiber). However, it is remarkable that despite of curauá is a leaf fiber, their general employment is for manufacture of composites instead of textile purposes.

The obtained values of regain (Table 1) are consistent with other ones of recognized textile employability lignocellulosic fibers (Table 2).

Tensile tests and weight on tururi fibrous material strips

The test was performed with 20 samples (cut strips of the fibrous material from the sacs of tururi) with dimensions of $20 \times 200 \mathrm{~mm}$ and an average thickness of $0.71 \mathrm{~mm}$. The results of the tensile test are shown in first line of Table 3.

Table 3 - Tensile tests on cut strips of the tururi fibrous material. Values expressed by average, standard coefficient and variation coefficient.

\begin{tabular}{cccccc}
\hline $\begin{array}{c}\text { Rupture Load } \\
(\mathbf{N})\end{array}$ & $\begin{array}{c}\text { Elongation } \\
\mathbf{( \% )}\end{array}$ & $\begin{array}{c}\text { Strength } \\
\mathbf{( M P a})\end{array}$ & $\begin{array}{c}\text { Young's modulus } \\
\mathbf{( M P a )}\end{array}$ & $\begin{array}{c}\text { Weight } \\
\mathbf{( g / \mathbf { m } ^ { 2 } )}\end{array}$ & References \\
\hline $\mathbf{2 1 3} \pm 93(43 \%)$ & $\mathbf{5 . 9} \pm 1.0(17 \%)$ & $\mathbf{1 7 . 6} \pm 7.8(44 \%)$ & $\mathbf{5 5 2} \pm 288(52 \%)$ & $\mathbf{1 8 2} \pm 18(10 \%)$ & {$[3][9]$} \\
391 & - & - & $1,800-2,400$ & $366-583$ & {$[29]$} \\
432 & 9.35 & - & - & 204.7 & {$[30]$} \\
558.3 & - & 12.27 & - & 246.37 & {$[31]$} \\
\hline
\end{tabular}

The values presented in Table 3 are similar (within the same order of magnitude). In the same way, for the weight values, but it is worthy of mention that for many tururi applications, it is stretched and the weight decreases in the proportion of its nonwoven structure opening.

There was no significant statistical variation between the tensile characteristics of the fibrous material in the natural condition (brown color) and after discoloration with hydrogen peroxide and solar illumination [3] [9]. 
Evaluation of cellulose, hemicellulose and lignin contents and crystallinity index

The values of cellulose, hemicellulose and lignin contents and crystallinity index for all fibers, excepted tucum fiber, were obtained in literature as presented in Table 4.

Table 4. Estimation of the concentrations of holocellulose and lignin in the tucum fiber through the analysis of the TGA and DTG curves. Other values were obtained from literature.

\begin{tabular}{|c|c|c|c|c|c|c|c|c|}
\hline \multirow{2}{*}{ Fiber } & \multicolumn{2}{|c|}{$\begin{array}{l}\text { Holocellulose } \\
\text { (wt \%) }\end{array}$} & \multirow{2}{*}{$\begin{array}{l}\text { Lignin } \\
\text { (wt\%) }\end{array}$} & \multirow{2}{*}{$\begin{array}{l}\text { Pectin } \\
\text { (wt\%) }\end{array}$} & \multirow[t]{2}{*}{ Waxes } & \multirow{2}{*}{$\begin{array}{c}\text { Extractives } \\
\text { (wt \%) }\end{array}$} & \multirow{2}{*}{$\begin{array}{c}\text { Crystallinity } \\
\text { Index } \\
(\%)\end{array}$} & \multirow{2}{*}{ References } \\
\hline & $\begin{array}{c}\text { Cellulose } \\
(\mathrm{wt} \%)\end{array}$ & $\begin{array}{c}\text { Hemicellulose } \\
\text { (wt\%) }\end{array}$ & & & & & & \\
\hline Tucum & & 68.4 & 21.7 & - & - & - & 80.25 & $\begin{array}{c}\text { [original } \\
\text { data] }\end{array}$ \\
\hline Buriti & & 65-71 & $21-27$ & - & - & $5.4-6.0$ & 71.2 & [32] \\
\hline Tururi & 74.1 & 12 & 31.1 & - & - & 0.5 & 60.6 & [29] [30] \\
\hline Sisal & 65-67 & 12 & 9.9 & $2-10$ & $2-10$ & $0.3-2$ & 57.3 & [32] \\
\hline Curaua & $71-74$ & $9.9-21$ & $7.5-11$ & - & $\begin{array}{c}0.79- \\
0.9\end{array}$ & $2.5-2.8$ & 43.5 & [32] \\
\hline
\end{tabular}

*Calculated according empirical method proposed by Segal et al. in 1959 [33]

According the results shown in Table 4 the obtained values are close. However, Segal's method [33] must be used with care, since it cannot able to reflect the real degree of biomass crystallinity, but instead provide a parameter for comparison. Even little variations in their compositions or cellulose crystallinity are expressive in order to determine differences in mechanical and thermal properties, being that higher tensile strength and higher thermal stability are obtained for fibers that contain more crystalline cellulose [32].

\section{FTIR}

The Fourier transform infrared spectroscopy (FTIR) from 4,000 to $500 \mathrm{~cm}^{-1}$ in equipment Thermo (model Avatar 370 FT-IR) employing cell of ATR / Germanium (Ge) (Nicolet, USA) comparing the spectra of three palm fibers from: (i) grown leaves of tucum (Astrocaryum chambira Burret); (ii) young leaves of buriti (Mauritia flexuosa Mart.); and (iii) sacs of tururi fibrous material (Manicaria saccifera Gaertn.); and two leaf fibers from: (i) curaua (Ananas erectifolius) and (ii) sisal (Agave sisalana) - is shown in Figure 3. 
Figure 3. FTIR from 4,000 to $500 \mathrm{~cm}^{-1}$ in equipment Thermo (model Avatar 370 FT-IR) employing cell of ATR / Germanium (Ge) (Nicolet, USA) - Transmittance from 96.4 to 99.8\%. From top to down: tucum (dark blue line), buriti (orange line), tururi (red line), sisal (light blue line) and curauá (red line). The overlap of FTIR spectra of 'linen' and 'draff' of buriti indicate a strong similarity between their chemical characteristics.

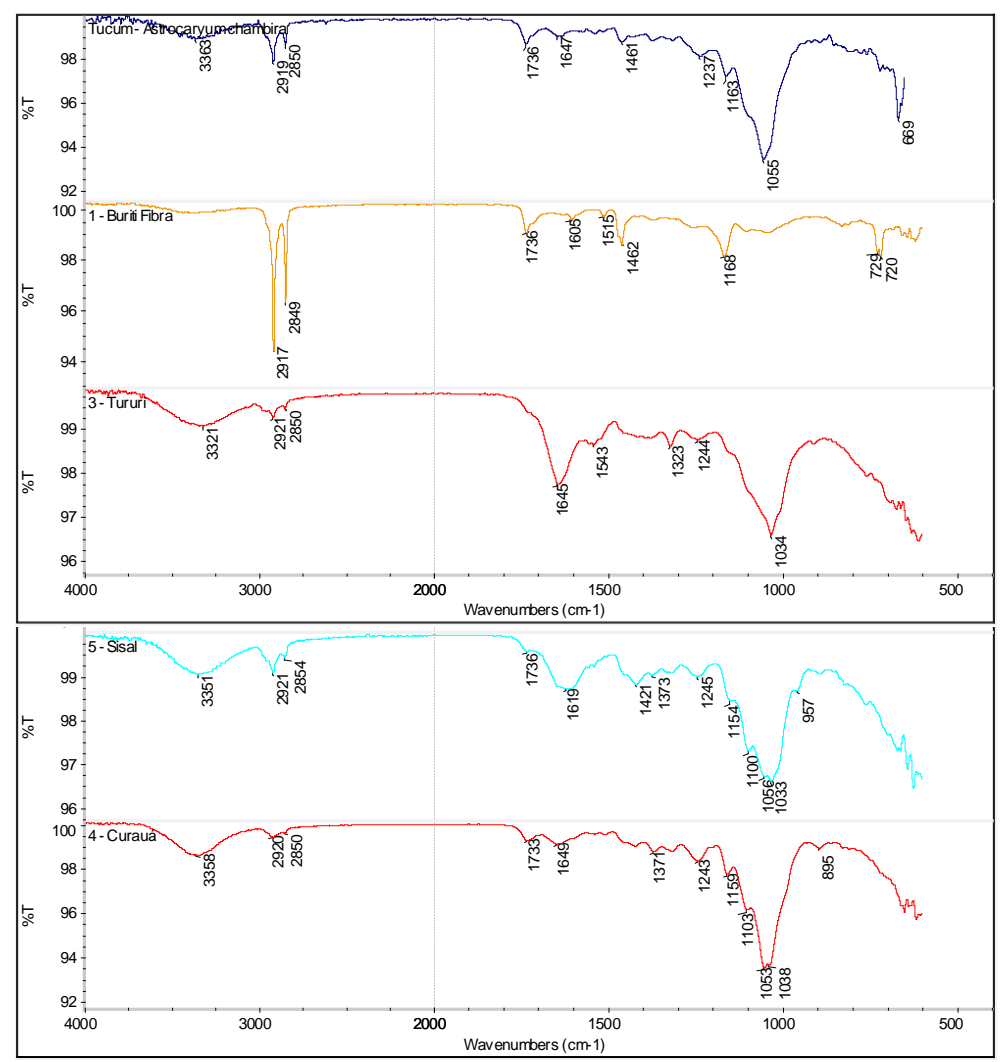

Taking in account the informations available by Stuart [34], an interpretation for the assignments of each fiber correspondent peak is presented in Table 5.

Analyzing the findings in Figure 3 and Table 5, it is possible to notice the great similarity in two wavenumber regions, near $3000 \mathrm{~cm}^{-1}$ and near the $3500 \mathrm{~cm}^{-1}$, indicating the presence of $\mathrm{CH}$ and $\mathrm{OH}$ respectively [35]. These are the major bands observed in the graphic, which was expected, since all analyzed materials have vegetal origin. It is still possible to compare the bands obtained around $1000 \mathrm{~cm}^{-1}$, in the region so called "fingerprint" of FTIR spectrum [34].

The characteristic absorption bands $\left(\mathrm{cm}^{-1}\right)$ for cotton are: 3450-3250; 2900; 1630; 1430; 1370; 1100-970; 550. These bands have similarity with the fibers analyzed in present study. Near the $1750 \mathrm{~cm}^{-1}$ band there is an area which indicates the presence of carbonyl group $(\mathrm{C}=\mathrm{O})$. The angular deformation between 3339 and $3564 \mathrm{~cm}^{-1}$ indicates the presence of hydroxyl groups which, in the cellulose chain are able to interact with each other, forming hydrogen bonds of two types: intramolecular (between the hydroxyl groups of the same chain), which are responsible for the stiffness of the chains, and intermolecular (between the hydroxyl groups of adjacent chains) are responsible for the formation of the supramolecular structure [36]. 
Thus, by FTIR analysis, considering the similarities and differences between the spectra (Figure 3 and Table 5), denoting different compositions and/or molecular structures and the presence of cellulose, hemicellulose and lignin in the fibers analyzed in present study.

Table 5. Infrared bands determined for tucum (Astrocaryum chambira), buriti (Mauritia flexuosa), tururi (Manicaria saccifera), sisal (Agave sisalana) and curaua (Ananas erectifolius) and their respective assignments.

\begin{tabular}{|c|c|c|c|c|c|}
\hline \multicolumn{5}{|c|}{ Wavenumber $\left(\mathrm{cm}^{-1}\right)$} & \multirow[t]{2}{*}{ Assignment $^{* * *}$} \\
\hline Tucum ${ }^{*}$ & Buriti" & Tururi** $^{* *}$ & Sisal" & Curaua** & \\
\hline 3363 & - & - & 3351 & 3358 & 3700-3200 O-H stretching \\
\hline - & - & 3321 & - & - & 3700-3200 O-H stretching \\
\hline 2919 & 2917 & 2921 & 2921 & 2920 & --- \\
\hline 2850 & 2849 & 2850 & 2854 & 2850 & 2900-2700 C-H aldehyde stretching \\
\hline 1736 & 1736 & - & 1736 & 1733 & 1740-1720 C=O aliphatic aldehyde stretching \\
\hline 1647 & - & 1645 & - & 1649 & 1680-1600 C=C stretching \\
\hline- & 1605 & - & - & - & 1680-1600 C=C stretching \\
\hline - & - & - & 1619 & - & 1680-1600 C=C stretching \\
\hline - & 1515 & - & - & - & --- \\
\hline ,- & - & 1543 & - & - & --- \\
\hline 1461 & 1462 & - & - & - & --- \\
\hline - & - & - & 1421 & - & --- \\
\hline - & - & - & 1373 & 1371 & --- \\
\hline - & - & 1323 & - & - & --- \\
\hline 1237 & - & 1244 & 1245 & 1243 & 1300-1100 C-O stretching \\
\hline 1163 & 1168 & - & 1154 & 1159 & 1300-1100 C-O stretching \\
\hline - & - & - & 1100 & 1103 & 1100 C-O-C stretching \\
\hline 1055 & - & - & 1056 & 1053 & --- \\
\hline - & - & 1034 & 1033 & 1038 & --- \\
\hline - & - & - & 957 & - & 1000-600 =C-H out-of-plane bending \\
\hline - & - & - & - & 895 & $1000-600=\mathrm{C}-\mathrm{H}$ out-of-plane bending \\
\hline - & 729 & - & - & - & 1000-600 =C-H out-of-plane bending \\
\hline - & 720 & - & - & - & 1003-600 =C-H out-of-plane bending \\
\hline 669 & - & - & - & - & 1004-600 =C-H out-of-plane bending \\
\hline
\end{tabular}

*original data; **[3] [9]; ***Assignments according the interpretation of informations by Stuart [34].

\section{Tururi composite development}

In a joint project of the North Carolina State University (USA) and University of Sao Paulo (Brazil), multilayer composite materials were developed and characterized in 3D structure with quite promising results in terms of resistance and aesthetic finish similar to wood. The goal of this research was to develop and characterize multilayer 3D green composites from Tururi fibrous material and identify applications based on their performance. A total of 12 composite samples were fabricated using Vacuum Assisted Resin Transfer Molding Technique (VARTM) to study the effect of the structural parameters, namely, number of Tururi fibrous layers, fiber orientation, and fiber volume fraction on the tensile and impact behavior of the final composites. It was found that increasing the \% stretch of the Tururi sac, and using an angle-ply stacking arrangement significantly reduced the anisotropy of the produced composite, and resulted in a quasiisotropic material. In the $0^{\circ} / 90^{\circ}$ arrangement, the tensile breaking load for $0 \%$ stretch was the same in the sac and cross directions, whereas in the $100 \%$ stretch it was random. Moreover, the breaking load of $100 \%$ stretch was generally higher than the $0 \%$ stretch. Additionally, when 
the breaking load was normalized by the preform areal density, it was found that composites with higher number of layers have lower normalized breaking load. Finally, increasing the stretch improved the resin penetration and increased the normalized breaking load. In the $0 \% / 45 \%$ $45^{\circ} / 90^{\circ}$ arrangement, the tensile breaking load for $100 \%$ stretch was the same in the sac and cross directions, whereas in the $0 \%$ stretch it was different. Moreover, the breaking load of $100 \%$ stretch was generally higher than the $0 \%$ stretch. Additionally, when the breaking load was normalized by the preform areal density, it was found that the number of layers and \% stretch have negligible effect on the normalized breaking load. It was found that a proper stacking sequence, can produce composites from tururi fibers with quasi-isotropic tensile behavior, and with the proper combination of number of layers, and stretch \%, the tensile properties of the produced composite can be optimized [11].

Furthermore, the impact properties of these composites were characterized in light of structural variables, namely, number of layers, fiber orientation, and \% stretch. It was found that the number of layers had the most significant effect on the impact resistance of the tururi composites, followed by the \% stretch, whereas the preform orientation had a slight significant effect on the normalized impact energy; moreover, it significantly affected the failure mechanism. Thus, in order to design composites from tururi fibers with high impact resistance, the first factor to be considered is the number of layers which should not exceed a certain threshold after which the resin penetration becomes impaired. The second factor is the \% stretch, which should be minimized to maintain higher fiber volume fraction. Finally, the fiber orientation should be random to improve the impact resistance, failure mechanism, and the damage tolerance of the structure [37].

The results are promising and indicate that tururi fibers are good candidate for the reinforcement of polymer composites. Natural fiber composites from tururi fibers exhibit a natural wood grain appearance; therefore, it can be used as a wood alternative in applications like floor laminates, counter tops, and indoor and outdoor furniture [11] [37].

\section{Conclusion}

The analyzed palm fibers (tucum, buriti and tururi) have employment potential in different kind of products, handcrafts or composites, which could generate articles such as utensils, furniture, flooring or construction. On the other hand, it is very important to preserve the palm species present in Amazon Forest biome, from which they are extracted in a sustainable way from local communities. Thus, more studies are necessary in order to know about the availability of this material thinking in an industrial scale. On the other hand, the work of local communities and craft cooperatives, which employ this material, could be stimulated respecting social and cultural aspects. The employment of natural fibers, in a sustainable context, bring implications of great importance to society, such us the environmental care, incoming generation and the possibility of qualifying the products produced by these communities adding technical and design attributes.

\section{References}

[1] I. M. Cattani, Buriti fiber (Mauritia flexuosa Mart.): registration in local community (Barreirinhas-MA, Brazil), physicochemical characterization and study of impregnation with resins, MSc thesis, University of Sao Paulo (Brazil), 2016.

https://doi.org/10.11606/d.100.2016.tde-29092016-100227 
[2] V. Froes et al., Especies botanicas do artesanato, in: V. Froes (Ed.), Linha do Tucum: Artesanato da Amazonia, Instituto de Estudos da Cultura Amazonica, Rio de Janeiro, 2010, pp. 72-105. https://doi.org/10.18542/amazonica.v6i2.1875

[3] A. S. Monteiro et al., Tururi palm fibrous material (Manicaria saccifera Gaertn.) characterization. Green Materials 3-4 (2016) 120-131. https://doi.org/10.1680/jgrma.15.00024

[4] N. Nunes, Documentary “Linha do Tucum: a linha da lealdade”. Direction Noilton Nunes. Production Imagine Filmes. 2009. 50 min. <http://youtu.be/RpbJH8lgzJ0>

[5] L. A. G. Pennas, J. Baruque-Ramos, Tucum fiber: reflections about Amazonian biodiversity, traditional knowledge and sustainable fashion, in: 4th International Fashion and Design Congress (CIMODE 2018), CRC Press/Balkema, Boca Raton, 2018, in press.

[6] M. A. Goulart, Buriti Photography Catalog. State of Maranhao (Brazil), 2014.

[7] I. M. Cattani, J. Baruque-Ramos, Brazilian Buriti Palm Fiber (Mauritia flexuosa Mart.), in: R. Fangueiro, S. Rana (Eds.), Natural Fibres: Advances in Science and Technology Towards Industrial Applications. Springer Netherlands, Heidelberg, 2016, pp. 89-98. https://doi.org/10.1007/978-94-017-7515-1_7

[8] I. M. Cattani, Video "Fibra de Buriti: da folha ao produto - Artesanato e Design”. 2016. 3:57 min. <https:/www.youtube.com/watch?v=ZAIgaxmmzvA>

[9] A. S. Monteiro, Tururi (Manicaria saccifera Gaertn.): textile characterization, processes and handicraft techniques in Amazon local community (PA - Brazil), MSc thesis, University of Sao Paulo (Brazil), 2016. https://doi.org/10.11606/d.100.2016.tde-04082016-144047

[10] A. S. Monteiro, J. Baruque-Ramos, Amazonian Tururi Palm Fiber Material (Manicaria saccifera Gaertn.) in: R. Fangueiro, S. Rana (Eds.), Natural Fibres: Advances in Science and Technology Towards Industrial Applications. Springer Netherlands, Heidelberg, 2016, pp. 127137. https://doi.org/10.1007/978-94-017-7515-1_10

[11] A. F. Seyam et al., Effect of structural parameters on the tensile properties of multilayer 3D composites from Tururi palm tree (Manicaria saccifera Gaertn) fibrous material. Composites Part B: Engineering 111 (2017) 17-26. https://doi.org/10.1016/j.compositesb.2016.11.040

[12] ABNT ISO 139:2005: Texteis - Atmosferas normais de condicionamento de ensaios ("Textiles - Standard atmospheres for conditioning tests").

[13] ABNT NBR 13 538-1995: Material textil - Analise qualitativa ("Textile material Qualitative analysis").

[14] B.P. Saville, Physical testing of textiles, The Textile Institute Woodhead Publishing Ltd., Cambridge, 2007.

[15] E. R. Kaswell, Wellington Sears Handbook of Industrial Textiles, Massachusetts Institute of Technology (MIT) and Wellington Sears Company, Cambridge, 1963.

https://doi.org/10.1201/9780203733905

[16] ASTM D 3 822-2001: Standard test method for tensile properties of single textile fibers. 
[17] ABNT NBR 13041:1993: Naotecido - Determinaçao da resistencia a traçao e alongamento Metodo de ensaio ("Nonwoven - Determination of tensile strength and elongation" - Test method").

[18] ABNT NBR 12984:2000: Naotecido - Determinaçao da massa por unidade de area - Metodo de ensaio ("Nonwoven - Determination of mass per area unit - Test method").

[19] ISO/TR 6741-4 -1987: Textiles - Fibres and yarns - Determination of commercial mass of consignments - Part 4: Values used for the commercial allowances and the commercial moisture regains. https://doi.org/10.3403/bsiso6741

[20] J. Bouchard et al., Quantification of residual polymeric families present in thermomechanical and chemically pretreated lignocellulosics via thermal analysis. Biomass 9(3) (1986) 161-171.

[21] Nicolet FT-IR User's Guide.

https://instrumentalanalysis.community.uaf.edu/files/2013/01/FT-IR_manual.pdf

[22] I. M. Cattani, J. Baruque-Ramos, Buriti palm fiber (Mauritia flexuosa Mart.): characterization and studies for its application in design products, Key Engineering Materials 668 (2016) 63-74. https://doi.org/10.4028/www.scientific.net/kem.668.63

[23] P. Ganan et al., I. Biological natural retting for determining the hierarchical structuration of banana fibers. Macromolecular Science 4 (2004) 978-983.

https://doi.org/10.1002/mabi.200400041

[24] R. S. Blackburn, Biodegradable and sustainable fibres. CRC Press and Woodhead Publishing Ltd., Cambridge, 2005.

[25] N. Reddy, Y. Yang, Properties and potential applications of natural cellulose fibers from cornhusks. Green Chemistry 7 (2005) 190-195. https://doi.org/10.1039/b415102j

[26] K. G. Satyanarayana et al., Studies on lignocellulosic fibers of Brazil. Part I: Source, production, morphology, properties and applications. Composites Part A: Applied Science and Manufacturing 38(7) (2007) 1694-1709. https://doi.org/10.1016/j.compositesa.2007.02.006

[27] M. A. S. Spinace et al., Characterization of lignocellulosic curaua fibres." Carbohydrate Polymers 77(1) (2009) 47-53. https://doi.org/10.1016/j.carbpol.2008.12.005

[28] N. Chand et al., SEM and strength characteristics of acetylated sisal fibre. Journal of materials science letters 8(11) (1989) 1307-1309. https://doi.org/10.1007/bf00721503

[29] A. Porras et al., Characterization of a novel natural cellulose fabric from Manicaria saccifera palm as possible reinforcement of composite materials. Composites Part B: Engineering 74 (2015) 66-73. https://doi.org/10.1016/j.compositesb.2014.12.033

[30] A. K. F. Oliveira, J. R. M. D'Almeida, Characterization of ubuçu (Manicaria saccifera) natural fiber mat. Polymers from Renewable Resources 5(1) (2014) 13.

https://doi.org/10.1177/204124791400500102

[31] C. Duarte, Fabrication and characterization of polyester resin composite reinforced with fabric of tururi fiber extracted from palm ubuçu - Manicaria saccifera. MSc thesis, Federal University of Para (Brazil), 2011. 
<http://repositorio.ufpa.br/jspui/bitstream/2011/5104/1/Dissertacao_FabricacaoCaracterizacaoM aterial.pdf>

[32] M. Poletto et al., Native cellulose: structure, characterization and thermal properties. Materials 7(9) (2014) 6105-6119.

[33] L. Segal et al., An empirical method for estimating the degree of crystallinity of native cellulose using the X-ray diffractometer. Textile Research Journal 29(10) (1959) 786-794. https://doi.org/10.1177/004051755902901003

[34] B. H. Stuart, Infrared Spectroscopy, Kirk-Othmer Encyclopedia of Chemical Technology, John Wiley \& Sons, Inc., New York, 2005. https://doi.org/10.1002/0471238961

[35] D. Ray, B. K. Sarkar, Characterization of alkali-treated jute fibers for physical and mechanical properties, Journal of Applied Polymer Science 80(7) (2001) 1013-1020. https://doi.org/10.1002/app.1184

[36] M. M. Houck, Identification of Textile Fibers, Woodhead Publishing, Cambridge, 2009.

[37] M. Midani et al., Effect of structural parameters on the impact properties of multilayer composites from tururi palm (Manicaria saccifera Gaertn.) fibrous material, Journal of Natural Fibers (2018) 1-14. https://doi.org/10.1080/15440478.2018.1491369 